Tạp chí Khoa học và Công nghệ biển T11 (2011). Số 2. Tr 49 - 65

\title{
TÌNH HÌNH Ô NHIỄM DÂUU TRONG NƯớC DẢI VEN BỜ VIỆT NAM
}

\author{
CAO THỊ THU TRANG, VŨ THỊ LỰU
}

Viện Tài nguyên và Môi trường biển

\begin{abstract}
Tóm tắt: Các kết quả quan trắc về nồng độ dầu trong nước dải ven biển Việt Nam trong hơn 10 năm qua cho thấy nuớc biển đã bi ô nhiếm bởi dầu và mức độ ô nhiếm ngày càng gia tăng. Các nguyên nhân gây ô nhiễm dầu trong nước bao gồm quá trình khai thác dầu trong thềm luc địa, quá trình chế biến dầu tại các co sở lọc dầu ven biển, hoạt động của hệ thống cảng biển trong vùng nước ven bò̀, các sự cố tràn dầu, tai nạn hàng hải. Các cuộc khảo sát mới nhất năm 2009 - 2010 tại 4 khu vục trọng điểm là Ha Long, Tam Giang - Cầu Hai, Vũng Tàu và Phú Quốc cũng cho thấy sư gia tăng của nồng độ dầu trong nước biển. Điều này cho thấy cần thiết phải kiểm soát các nguồn thải dầu mõ trên vùng biển nhằm góp phần giũ gìn chất lượng môi truờng, bảo vệ nguồn tài nguyên biển và đa dạng sinh học.
\end{abstract}

\section{MỞ ĐÀ̀U}

Tình hình ô nhiễm dầu trong nước dải ven bờ Việt Nam trong những năm gần đây rất đáng báo động và cần được sự cảnh báo của các nhà khoa học và các nhà quản lý. Có nhiều nguyên nhân gây ra ô nhiễm dầu trong nước vùng ven biển như quá trình khai thác dầu trong thềm lục địa, quá trình chế biến dầu tại các cơ sở lọc dầu ven biển, hoạt động của hệ thống cảng biển trong vùng nước ven bờ, các sự cố tràn dầu, tai nạn hàng hải. Sản lượng khai thác dầu khí tăng lên hàng năm, nếu như năm 1996, sản lượng dầu là 8,8 triệu tấn thì đến năm 2010 là 24,41 triệu tấn (theo Petro Việt Nam), tăng gần 3 lần so với năm 1996. Ngoài ra số lượng tàu vận tải cũng như sản lượng vận tải biển thông qua hệ thống các cảng biển Việt Nam ngày càng gia tăng. Theo Cục Hàng hải Việt Nam, năm 2009 sản lượng hàng hóa thông qua hệ thống cảng biển Việt Nam đạt 251,2 triệu tấn, tăng 17,7\% so với năm 2008 , lượt tàu ra vào cảng tăng $9,56 \%$ so với năm 2008 . Điều này cho thấy, với sự phát triển nhanh chóng của các ngành kinh tế liên quan, nguy cơ ô nhiễm dầu trên dải ven bờ Việt Nam là rất tiềm tàng.

Bài báo "Tình hình ô nhiễm dầu trong nước dải ven bờ Việt Nam” với mục đích đánh giá hiện trạng nồng độ dầu trong nước biển tại một số khu vực trọng điểm của Việt Nam để từ đó có được bức tranh tổng quan về sự phân bố nồng độ dầu trong nước biển. Nguồn số liệu từ năm 2009 - 2010 chủ yếu trích từ dự án "Xây dưng co sở khoa học, pháp lý cho việc 
đánh giá và đòi bồi thuoòng thiệt hai do ô nhiễm dầu gây ra trên vùng biển Việt Nam”. Tập thể tác giả xin cảm ơn $\mathrm{BCN}$ dự án đã hỗ trợ tạo điều kiện về số liệu để thực hiện.

\section{PHƯƠNG PHÁP VÀ TÀI LIỆU NGHIÊN CÚU}

Các phương pháp nghiên cứu sử dụng trong bài báo bao gồm:

- Phương pháp điều tra khảo sát biển: Các mẫu dầu trong nước được thu bằng bathomet tại 4 khu vực trong điểm nghiên cứu của Việt Nam là Hạ Long, Huế, Vũng Tàu và Phú Quốc (hình 1). Mẫu được thu đại diện cho hai mùa khô và mưa của Việt Nam vào các năm 2009 và 2010.

- Phương pháp phân tích mẫu trong phòng thí nghiệm: Mẫu dầu sau khi thu được bảo quản và chuyển về phòng thí nghiệm để phân tích. Dầu trong nước được chiết bằng $\mathrm{n}$ hexan, sau đó làm khan bằng $\mathrm{Na}_{2} \mathrm{SO}_{4}$ khan và xác định bằng phương pháp so màu [1].

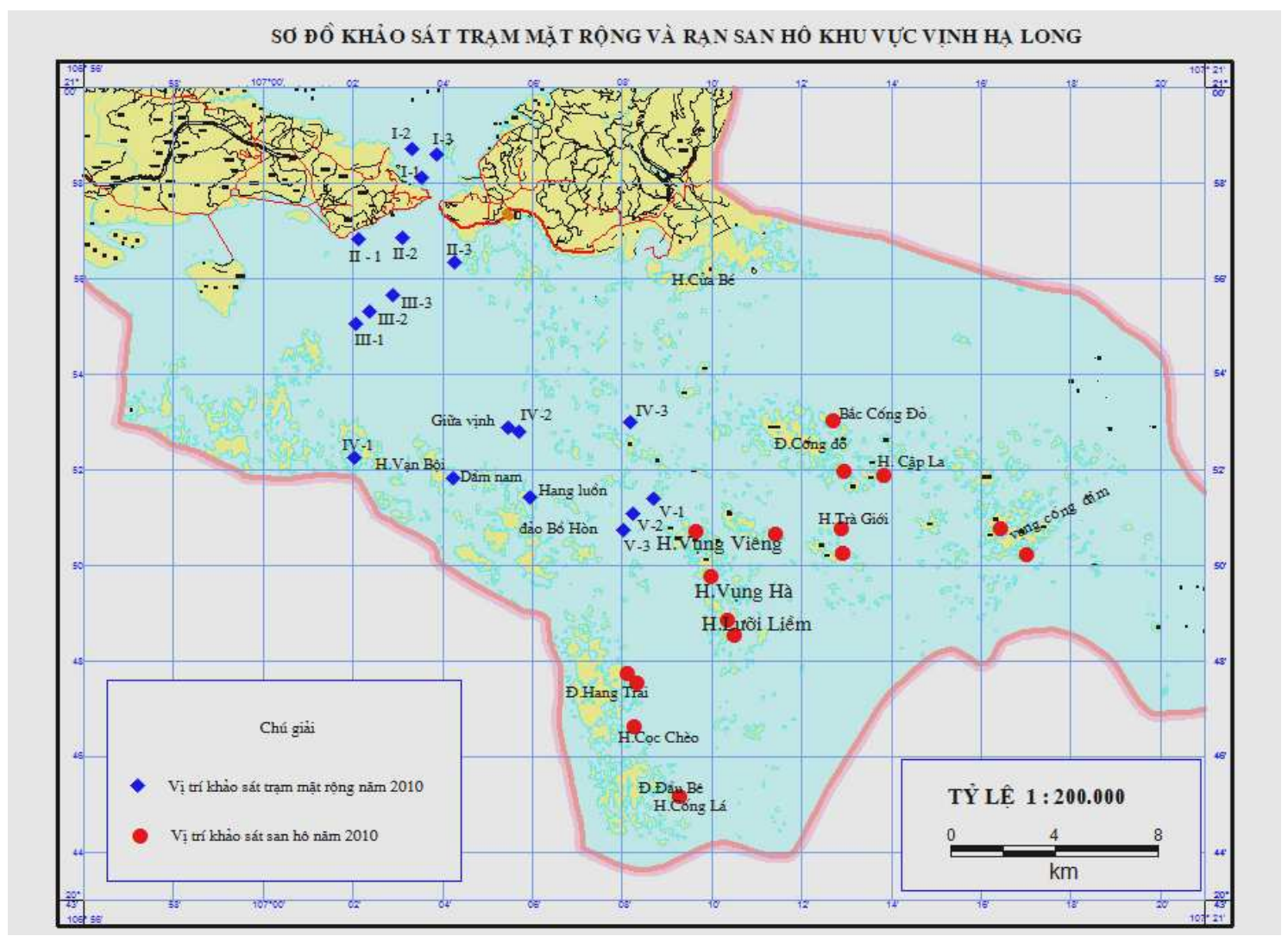

Hình 1a 


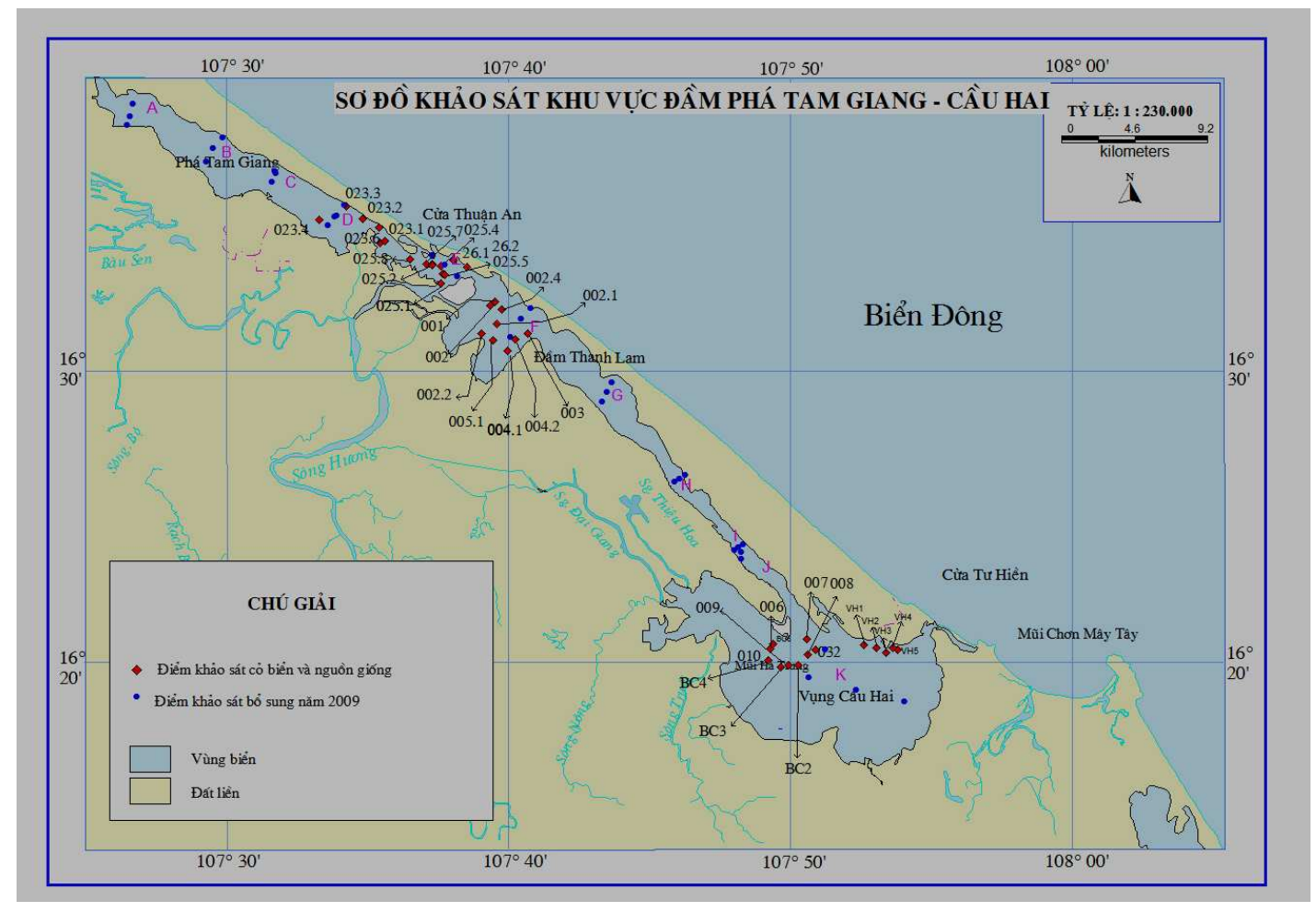

Hình 1b

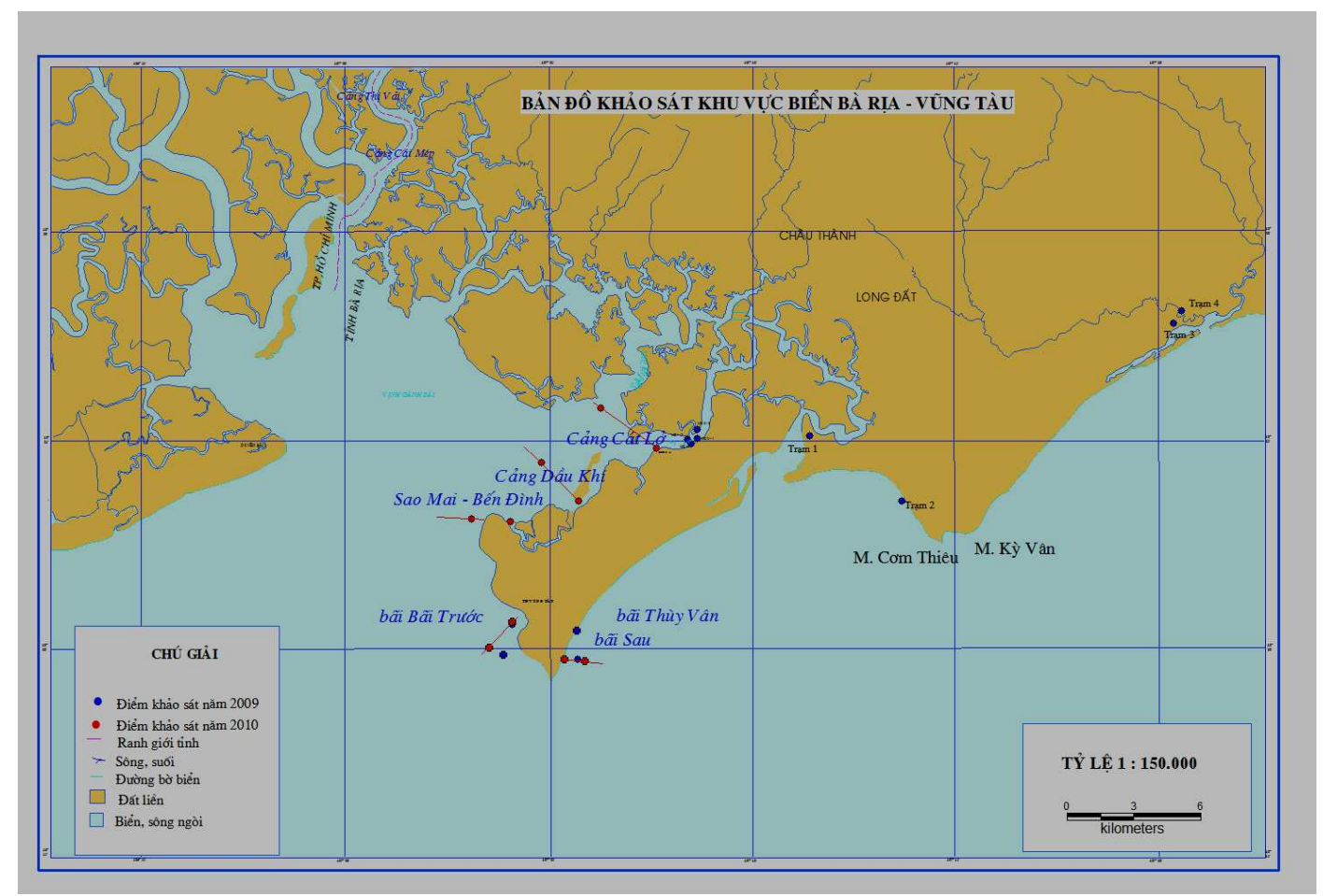

Hình 1c 


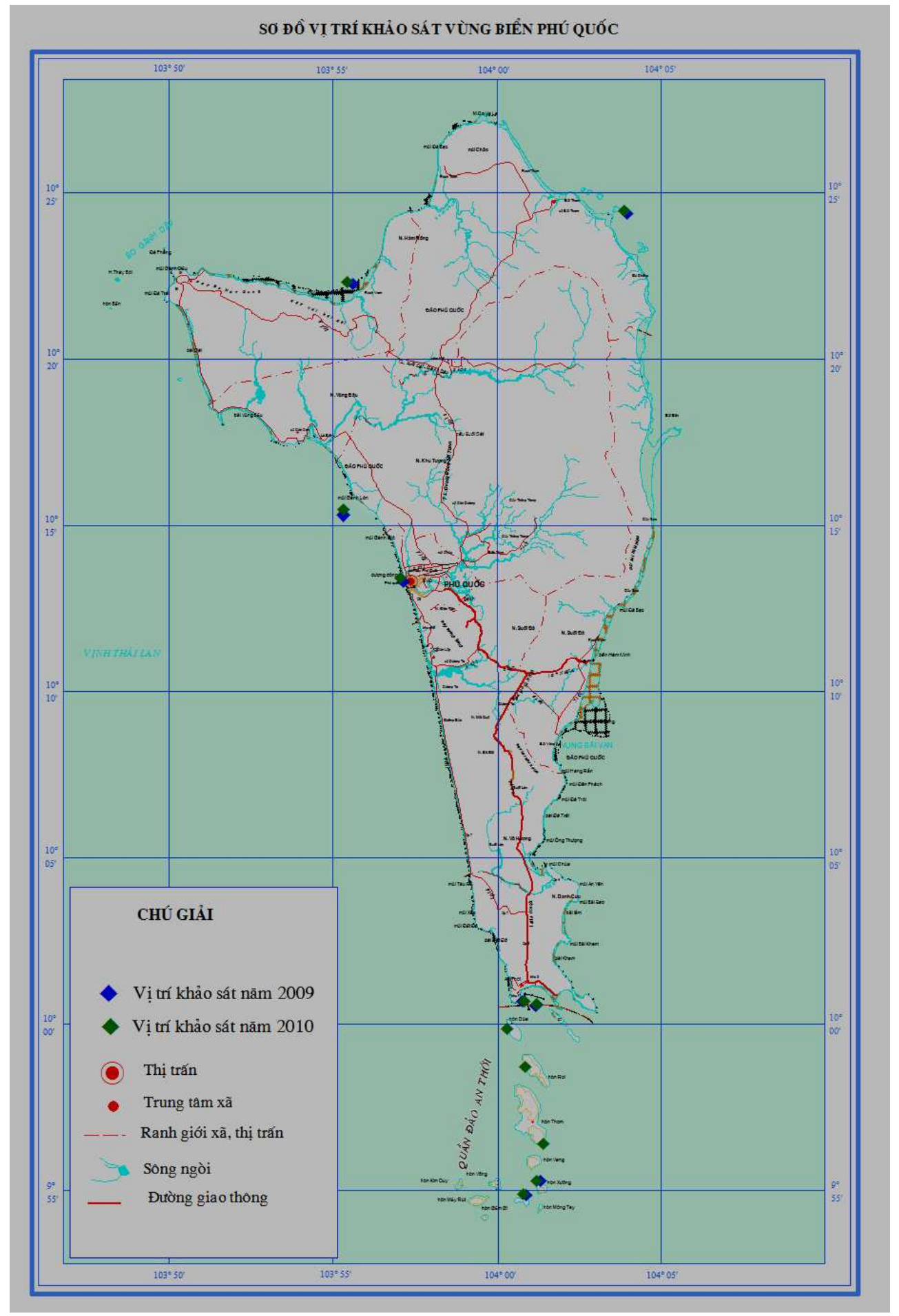

Hình 1d

Hình 1: Sơ đồ trạm khảo sát các khu vực biển vịnh Hạ Long (1a), Tam Giang - Cầu Hai (1b), Vũng Tàu (1c) và Phú Quốc (1d) 
- Phương pháp thu thập và đánh giá tài liệu: Các tài liệu về sự phân bố nồng độ dầu trong nước dải ven biển Việt Nam được thu thập và đánh giá, bao gồm:

+ Số liệu quan trắc hàng năm của Trạm quan trắc và Phân tích môi trường Biển miền Bắc [16].

+ Dự án hợp tác Việt - Ý thực hiện năm 2004 - 2005 của Viện Tài nguyên và Môi trường Biển thực hiện tại khu vực đầm phá Tam Giang - Cầu Hai [2, 3].

+ Dự án IMOLA (Ý) thực hiện năm 2006 - 2007 tại khu vực đầm phá Tam Giang Cầu Hai [7, 12].

+ Đề tài Kiểm kê đánh giá các khu vực, đối tượng có giá trị kỳ quan thiên nhiên, di sản tự nhiên ở vùng biển và ven bờ Thừa Thiên Huế năm 2008 [4]

+ Nhiệm vụ cấp cơ sở của Viện Tài nguyên và Môi trường biển thực hiện năm 2008 tại Vũng Tàu [13].

+ Đề tài ĐDSH vịnh Hạ Long phục vụ cho việc nâng cao giá trị của di sản, năm 2007 - 2008 [14].

+ Điểm trình diễn rạn san hô và thảm cỏ biển tại Phú Quốc, trong khuôn khổ Dự án khu vực (UNEP/GEF/SCS) - Viện TN và MT Biển thực hiện năm 2007 [18].

\section{KẾT QUẢ NGHIÊN CÚU}

\section{Tình hình ô nhiễm dầu 4 trọng điểm khảo sát}

\subsection{Khu vục Hạ Long - Cát Bà:}

Theo các kết quả điều tra, nghiên cứu, vùng nước vịnh Hạ Long được đánh giá là có mức độ ô nhiễm dầu khá cao. Theo đó, vùng nước cảng Cái Lân có thời điểm nồng độ dầu trong nước biển đạt tới 1,75mg/l gấp 8.75 lần QCVN 10:2008/BTNMT $(0,2 \mathrm{mg} / \mathrm{l})$ và gấp hàng chục lần tiêu chuẩn ASEAN, có đến $1 / 3$ diện tích mặt vịnh thường xuyên có nồng độ dầu từ 1 đến 1,73 mg/l (Dự án CANADA T7/1998 - Viện Tài nguyên và Môi trường Biển) [8]. Bằng mắt thường, có thể thấy, tại cảng tàu du lịch Bãi Cháy, âu tàu Tuần Châu, các khu neo đậu tàu du lịch ở các điểm tham quan du lịch trên vịnh, khu neo đậu tàu vụng Đâng, Lán Bè, Bến Đoan, cảng xăng dầu B12, cảng Cái Lân, khu công nghiệp đóng tàu Giếng Đáy... đều thường xuyên có váng dầu loang rộng trên mặt nước. Việc gia tăng một cách nhanh chóng các phương tiện vận tải thủy hoạt động thường xuyên trên vịnh Hạ Long là một trong những nguyên nhân chính gây ô nhiễm dầu cho vịnh. 
Theo kết quả của đề tài "Nghiên cứu, đánh giá các giá trị đa dạng sinh học vịnh Hạ Long phục vụ cho việc quản lý, phát huy giá trị đa dạng sinh học của của di sản" (Đỗ Công Thung và nnk, 2009) nồng độ dầu quan trắc tháng 7 - 2007 tại 32 trạm trong vịnh Hạ Long cho thấy nồng độ dầu trong nước dao động từ 0,07 đến $2,32 \mathrm{mg} / 1$, trung bình 0,65 $\mathrm{mg} / 1$. So với GHCP đối với nước ven bờ theo QCVN 10: 2008/BTNMT đối với nước các nơi khác $(0,20 \mathrm{mg} / \mathrm{l})$, nồng độ dầu tại 19/32 trạm cao hơn GHCP từ 1,05 đến 11,6 lần. Các kết quả quan trắc lặp lại vào tháng 12/2007 tại 21 trạm cho thấy nồng độ dầu trong nước trong khoảng từ 0,07 đến $2,01 \mathrm{mg} / \mathrm{l}$, trung bình $0,36 \mathrm{mg} / \mathrm{l}$ và có $11 / 21$ trạm vượt $\mathrm{GHCP}$ từ 1,1 đến 10,1 lần. Các kết quả quan trắc tháng 12 - 2008 tại 8 trạm trong vịnh Hạ Long cho thấy nồng độ dầu trong nước dao động từ 0,19 đến $0,59 \mathrm{mg} / 1$, trung bình $0,32 \mathrm{mg} / \mathrm{l}$. Có $6 / 8$ trạm vượt GHCP từ 1,1 đến 2,95 lần (hình 2).

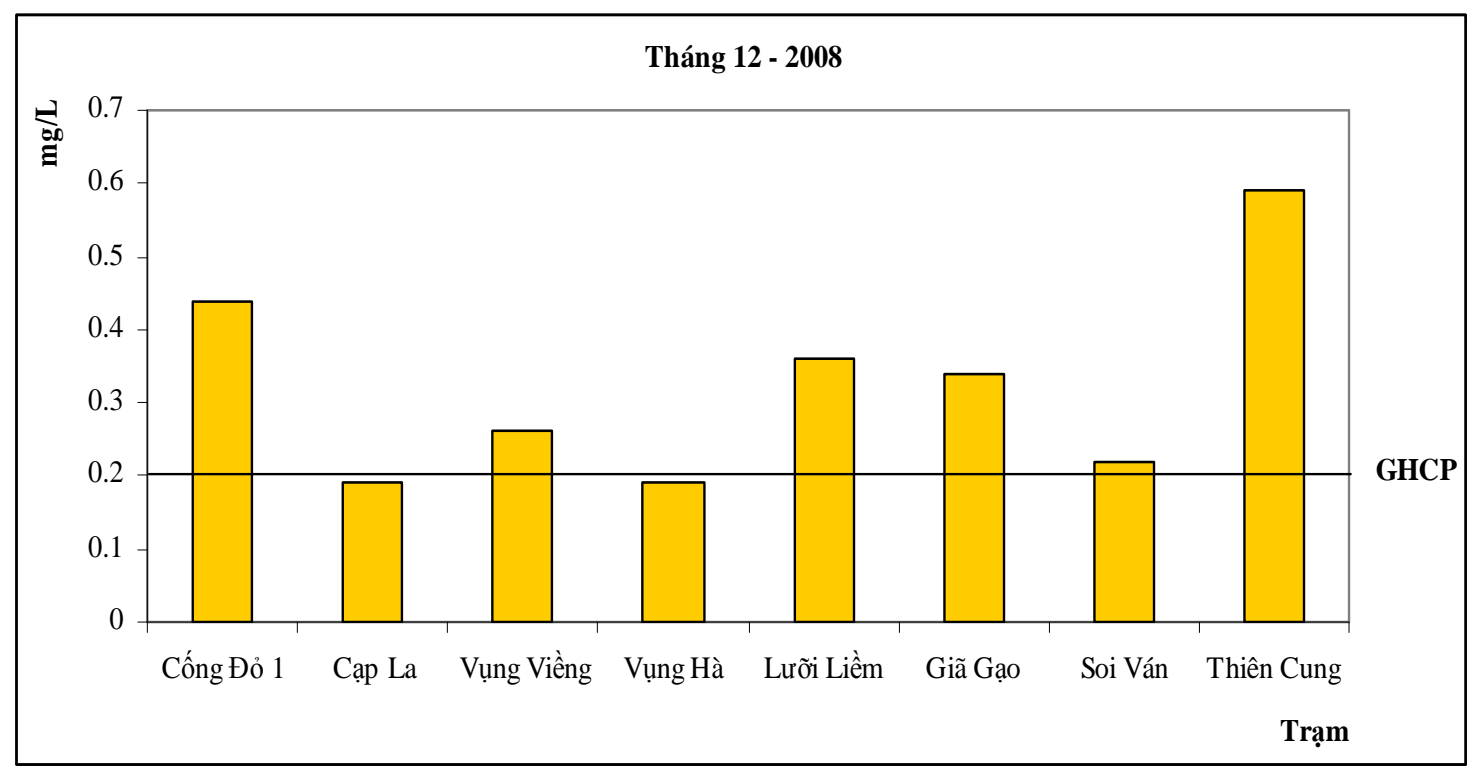

Hình 2: Nồng độ dầu trong nước tầng mặt Vịnh Hạ Long tháng 12 - 2008 (Nguồn: Đố Công Thung và nnk, 2009 [14])

Nồng độ dầu quan trắc tháng 9 - 2009 tại 15 trạm trên Vịnh Hạ Long (hình 1a) dao động từ 0,11 đến $3,55 \mathrm{mg} / \mathrm{l}$, trung bình $0,75 \mathrm{mg} / \mathrm{l}$. So với $\mathrm{GHCP}$ đối với nước ven bờ theo $\mathrm{QCVN}$ 10: 2008/BTNMT đối với nước các nơi khác $(0,20 \mathrm{mg} / \mathrm{l})$, nồng độ dầu tại 10/15 trạm cao hơn GHCP từ 1,1 đến 17,8 lần. Nồng độ dầu quan trắc tháng 4 - 2010 tại 11 trạm dao động từ 0,16 đến $1,25 \mathrm{mg} / \mathrm{l}$, trung bình $0,51 \mathrm{mg} / \mathrm{l}$, có $9 / 11$ mẫu dầu cao hơn $\mathrm{GHCP}$ từ 1,3 đến 6,3 lần. Nồng độ dầu tại các mặt cắt II, III, IV, V đều vượt giới hạn cho phép (hình 3). 
Trong 5 mặt cắt được thiết kế, mặt cắt I là khu vực cảng Cái Lân, mặt cắt II là khu vực phía ngoài của Cửa Lục, mặt cắt III và IV là ở giữa vịnh Hạ Long, mặt cắt $\mathrm{V}$ là hòn vụng Viêng - khu vực có nhiều rạn san hô. Nồng độ dầu trong nước có giá trị cao nhất tại khu vực giữa vịnh Hạ Long, tiếp đến là khu vực gần rạn san hô, phải chăng liên quan đến sự xả thải dầu của các tàu thuyền phục vụ du lịch. Trong khi đó, nồng độ dầu phía cảng Cái Lân lại thấp hơn so với các khu vực khác. Các kết quả quan trắc bổ sung vào tháng 11/2010 tại khu vực tại 3 trạm cảng Cái Lân và 1 trạm ở Cửa Lục cũng cho kết quả tương tự, nồng độ dầu trung bình MC I và II tương ứng là 0,23 và $0,69 \mathrm{mg} / \mathrm{l}$, trong đó có sự gia tăng nồng độ dầu trong nước tại Cửa Lục.

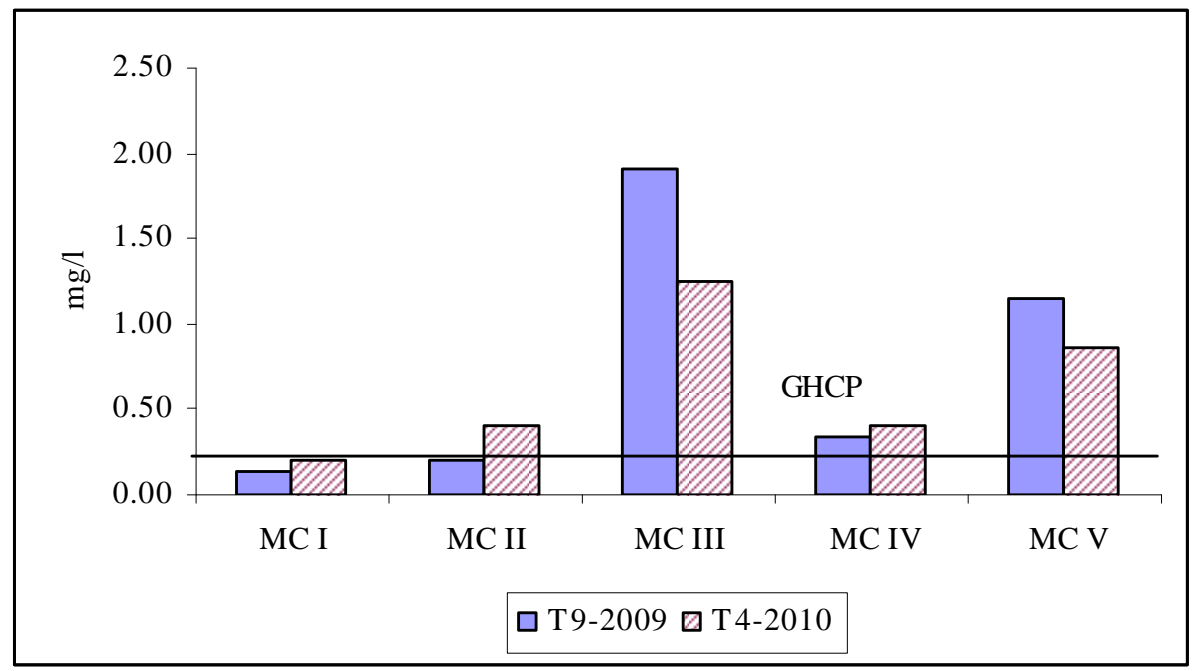

Hình 3: Nồng độ dầu trong nước tầng mặt vịnh Hạ Long năm 2009 - 2010

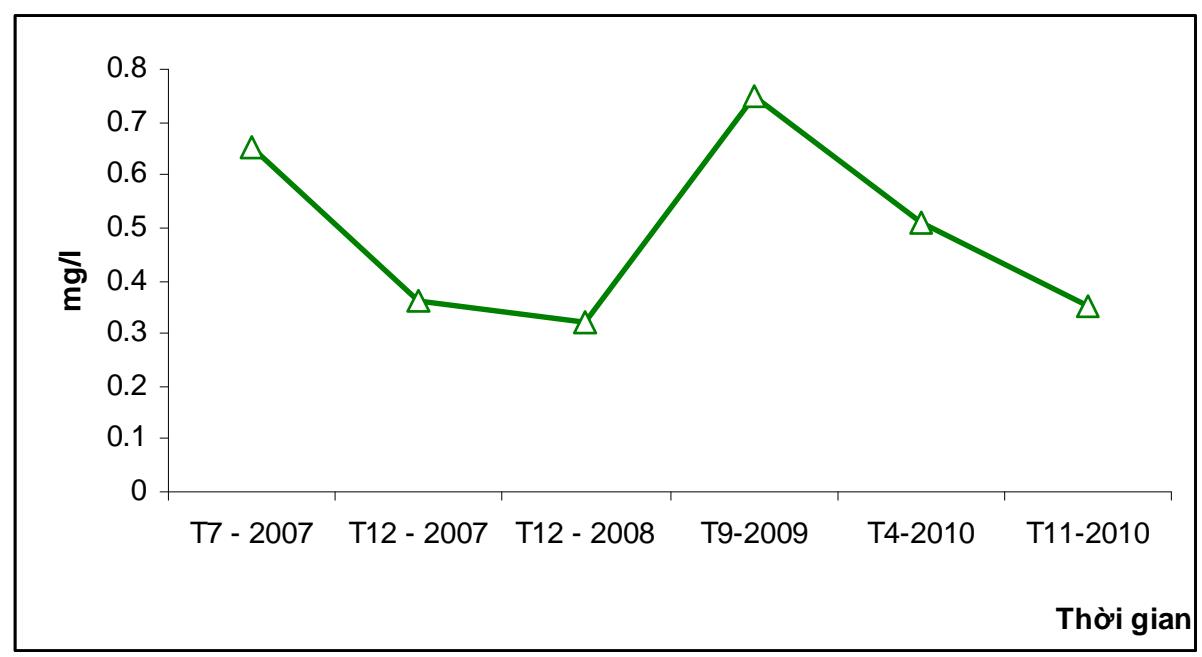

Hình 4: Diễn biến nồng độ dầu trung bình trong nước Vịnh Hạ Long theo thời gian 
Tính trung bình, nồng độ dầu trong nước vịnh Hạ Long các năm từ 2007 đến 2010 dao động từ 0,32 đến $0,75 \mathrm{mg} / \mathrm{l}$. So với $\mathrm{GHCP}$ đối với nước biển ven bờ theo QCVN 10 : 2008/BTNMT dùng cho các mục đích khác $(0,20 \mathrm{mg} / \mathrm{l})$, nồng độ dầu trung bình trong nước cao hơn GHCP từ 1,6 đến 3,8 lần. Nồng độ dầu tháng 9 - $2009(0,75 \mathrm{mg} / \mathrm{l})$ cao hơn các năm khác (hình 4).

\subsection{Khu vục Tam Giang - Cầu Hai}

Hệ đầm phá Tam Giang - Cầu Hai kéo dài theo phương Tây Bắc - Đông Nam dọc theo bờ biển, có chiều dài $68 \mathrm{~km}$, tổng diện tích mặt nước $216 \mathrm{~km} 2$ và gồm 3 đầm, phá hợp thành: phá Tam Giang, đầm Thuỷ Tú và đầm Cầu Hai .

Các kết quả khảo sát chất lượng nước trong các năm từ 1995 đến năm 2006, cho thấy theo thời gian, mức độ ô nhiễm dầu trong nước khu vực đầm phá Tam Giang - Cầu Hai tăng lên. Năm 1995, mức độ ô nhiễm dầu trong vùng khá thấp, hệ số rủi ro bằng 0,8, trong các khu vực chỉ có cửa Thuận An có biểu hiện bị ô nhiễm (hệ số rủi ro đạt $1,1)$. Các năm từ 1996 đến 2001, hệ số rủi ro dao động từ 1,2 đến 2,7 và có xu hướng tăng dần. Kết quả khảo sát tháng 6 năm 2004, nồng độ dầu trong nước dao động từ 0,21 - 0,53 mg/l, 100\% số mẫu có nồng độ dầu vượt $\mathrm{GHCP}(0,20 \mathrm{mg} / \mathrm{l})$. Nồng độ dầu trong nước toàn vùng, tháng 9 năm 2005 dao động từ $0,27-0,51 \mathrm{mg} / 1$, số mẫu vượt $\mathrm{GHCP}$ là 100\%. Tháng 11 năm 2006, nồng độ dầu trong nước đầm phá dao động từ $0,19-0,76$ $\mathrm{mg} / \mathrm{l}$, trong số 21 mẫu có tới 20 mẫu có nồng độ dầu vượt GHCP (theo số liệu tổng hợp từ các đề tài được thực hiện tại vùng đầm phá Tam Giang - Cầu Hai của Viện Tài nguyên và Môi trường Biển). Kết quả khảo sát bổ sung tháng 6/2008 cũng cho kết quả nồng độ dầu đạt $0,87 \mathrm{mg} / \mathrm{l}$ tại đầm Thuỷ Tú. Kết quả này lớn hơn GHCP đối với nước nuôi trồng thuỷ sản khoảng 4,35 lần.

Trong khuôn khổ dự án IMOLA “Tài nguyên và Môi trường đầm phá Tam Giang Cầu Hai”, 21 trạm thu mẫu dầu đã được thiết kế trên khắp khu vực toàn đầm phá. Các kết quả khảo sát và phân tích cho thấy, nồng độ dầu trong nước toàn khu vực dao động từ $0,185-0,822 \mathrm{mg} / \mathrm{l}$, trung bình toàn vùng $0,402 \mathrm{mg} / \mathrm{l}$. Có $36 / 42$ mẫu (chiếm $86 \%$ ) với giá trị nồng độ dầu trong nước lớn hơn $\mathrm{GHCP}(0,2 \mathrm{mg} / \mathrm{l})$. Các khu vực có nồng độ dầu trong nước cao là cửa Thuận An, đầm Cầu Hai. Sự chênh lệch nồng độ dầu trong nước giữa mùa mưa nhiều (tháng 11) và mùa ít mưa (tháng 8) là không lớn (hình 5).

Các kết quả quan trắc nồng độ dầu mỡ trong nước các khu vực có thảm cỏ biển Tam Giang - Cầu Hai năm 2009 cho thấy nồng độ dầu trong nước khá cao, dao động từ 0,37 $0,68 \mathrm{mg} / \mathrm{l}$, lớn hơn $\mathrm{GHCP}(0,2 \mathrm{mg} / \mathrm{l})$ từ 1,9 đến 3,4 lần. Tháng 9 , nồng độ dầu trong nước tăng cao hơn mùa khô (tháng 4) trung bình khoảng 1,5 lần. Nồng độ dầu tại Ba Cồn cao nhất, tiếp đến là Cồn Nổi và Cồn Tè (hình 6). 


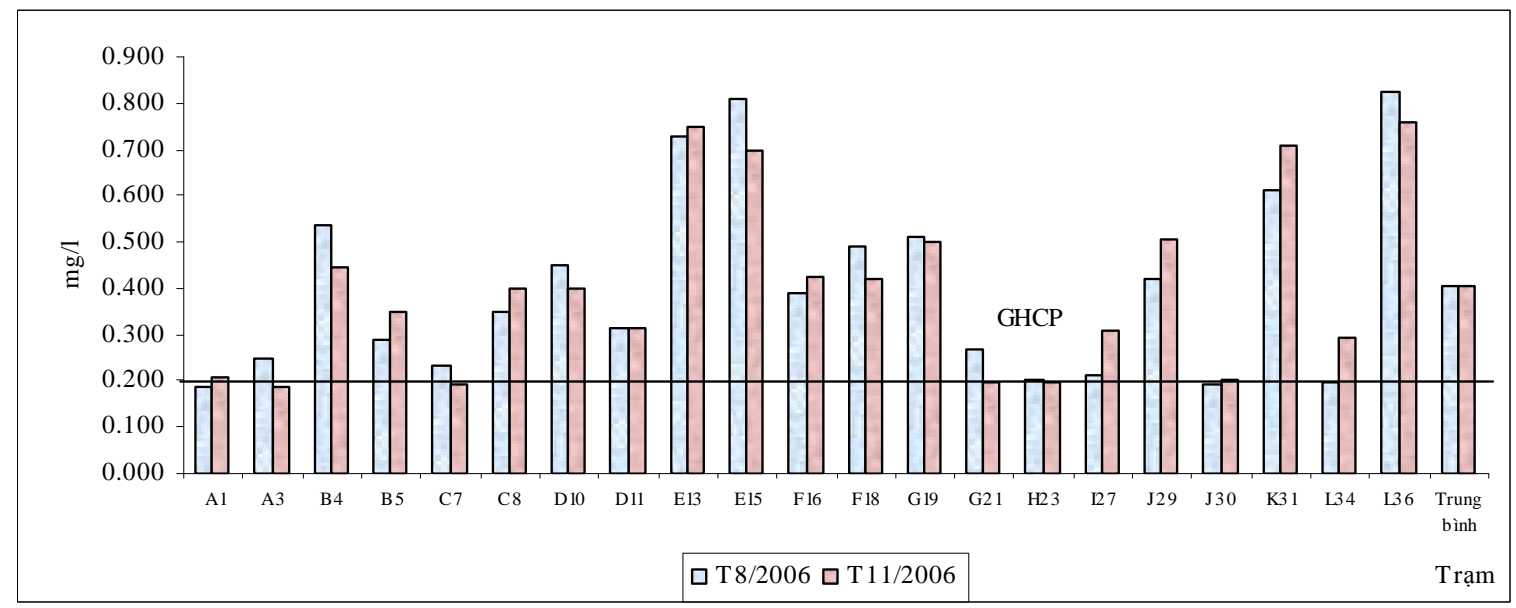

Hình 5: Nồng độ dầu trong nước khu vực đầm phá Tam Giang - Cầu Hai năm 2006 (Nguồn: IMOLA, 2007) [7]

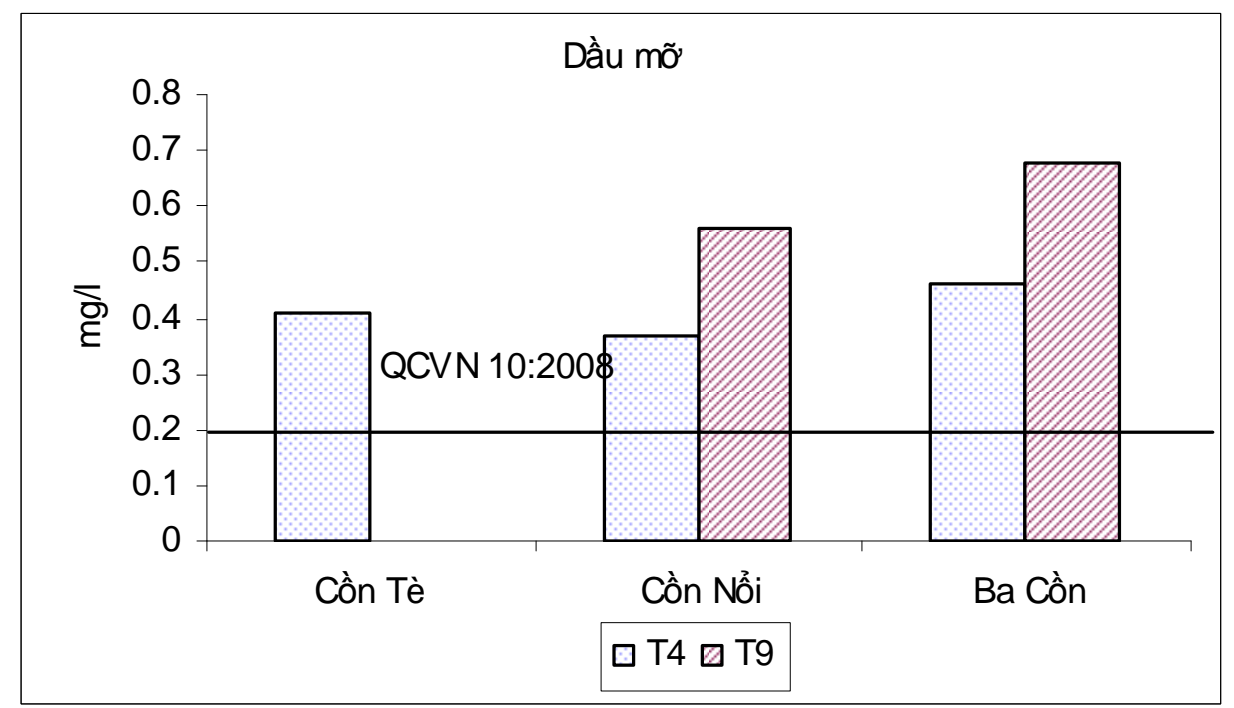

Hình 6: Nồng độ dầu trong nước biển phá Tam Giang - Cầu Hai năm 2009 (Nguồn: Nguyến Huy Yết và nnk, 2010) [20]

Các kết quả quan trắc mới nhất về nồng độ dầu trong nước biển phá Tam Giang Cầu Hai trong khuôn khổ của dự án "Xây dụng co sở khoa học, pháp lý cho việc đánh giá và đòi bồi thuoòng thiệt hại do ô nhiếm dầu gây ra trên vùng biển Việt Nam" tại 15 trạm khảo sát vào tháng $10 / 2009$ và tháng $3 / 2010$ (hình $1 b$ ) cho thấy nồng độ dầu trong nước dao động từ 0,16 - 0,79 mg/l, với $93 \%$ số mẫu vượt $\mathrm{GHCP}(0,2 \mathrm{mg} / \mathrm{l})$ từ hơn 1 đến 4 lần. 
Các khu vực có nồng độ dầu trong nước cao hơn vẫn là khu vực cửa Thuận An, đầm Sam và đầm Cầu Hai.



Hình 7: Nồng độ dầu trong nước khu vực đầm phá Tam Giang - Cầu Hai năm 2009 2010 (Nguồn Đố Công Thung và nnk, 2010) [15]

Quan trắc nồng độ dầu mỡ phá Tam Giang - Cầu Hai từ năm 2004 đến nay cho thấy có sự tăng nhẹ nồng độ dầu trong nước biển, trong đó đợt quan trắc tháng 12 năm 2006 đã bắt gặp mẫu có nồng độ dầu trong nước khá cao

\subsection{Khu vục Vũng Tàu}

Tại các khu vực cảng biển, từ năm 1999 đến 2001 đã xác định nồng độ dầu trong nước dao động từ $0,14 \mathrm{mg} / \mathrm{l}$ đến $0,52 \mathrm{mg} / \mathrm{l}$ (Nguyễn Thanh Hùng, 2005) [9]. Các kết quả quan trắc vào tháng 5 năm 2004 tại 3 vị trí vùng bờ biển cho thấy nồng độ dầu trong nước khá cao, trong khoảng $0,3-0,71 \mathrm{mg} / \mathrm{l}$, trung bình $0,48 \mathrm{mg} / \mathrm{l}$. Năm 2008 , hàm lựong dầu cao hơn, từ $0,37-1,69 \mathrm{mg} / \mathrm{l}$, trung bình $1.12 \mathrm{mg} / \mathrm{l}$, lớn hơn GHCP rất nhiều. Nồng độ dầu cao tại vùng biển Vũng Tàu vào thời gian đó là do bị ảnh hưởng của vụ chìm tàu Đức Trí gây ra. Trong khuôn khổ dự án "Xây dưng co' sở khoa hoc, pháp lý cho viẹc đánh giá và đòi bồi thuoòng thiệt hại do ô nhiếm dầu gây ra trên vùng biển Việt Nam, [15] 16 mẫu dầu trong nước biển đã được thu vào tháng 5/2009 và tháng 10/2009 tại khắp vùng biển ven bờ của Vũng Tàu. Các kết quả phân tích cho thấy nồng độ dầu trong nước ven biển Vũng Tàu nằm trong khoảng từ $0,08 \mathrm{mg} / \mathrm{l}$ đến $1,07 \mathrm{mg} / \mathrm{l}$, nồng độ dầu trung bình của đợt thu mẫu tháng 5 là $0,46 \mathrm{mg} / \mathrm{l}$, của đợt thu mẫu tháng 10 là $0,18 \mathrm{mg} / \mathrm{l}$, trong đó lượng mẫu vượt $\mathrm{GHCP}(0,2 \mathrm{mg} / \mathrm{l})$ là $100 \%$ vào đợt thu mẫu tháng 5 và $38 \%$ vào đợt thu mẫu tháng 10 (hình 8). 


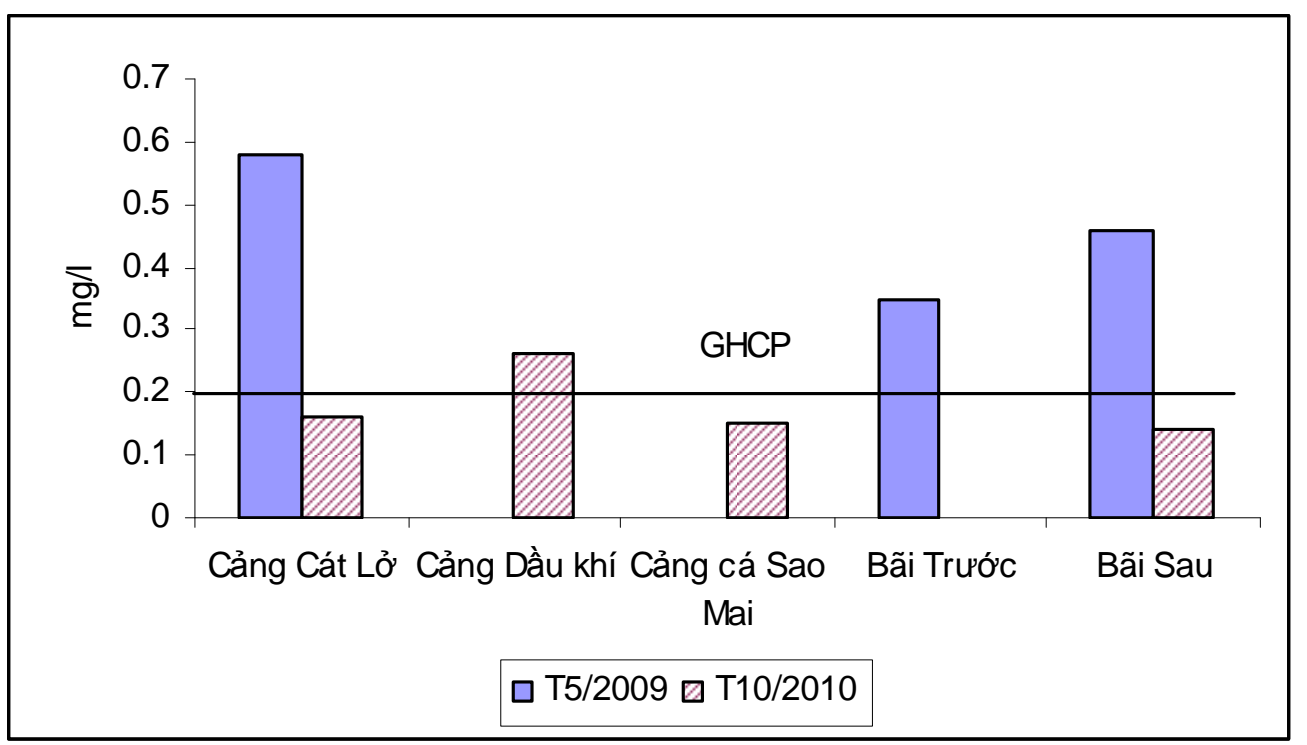

Hình 8: Nồng độ dầu trung bình trong nước tại các khu vực ven biển Vũng Tàu năm 2009 - 2010

\subsection{Khu vục ven đảo Phú Quốc}

Kết quả cho thấy, nồng độ dầu trong nước tháng 12/2007 tại vùng biển Phú Quốc dao động trong khoảng $0,19-0,26 \mathrm{mg} / \mathrm{l}$, trung bình $0,23 \mathrm{mg} / \mathrm{l}$, cao hơn GHCP. Năm 2009, 2010, các đợt quan trắc chất lượng nước đảo Phú Quốc đã xác định nồng độ dầu trong nước đảo Phú Quốc dao động từ 0,08 đến $0,26 \mathrm{mg} / \mathrm{l}$, trung bình $0,15 \mathrm{mg} / \mathrm{l}$. Các chuyến khảo sát nồng độ dầu trong nước vùng biển Phú Quốc đã được thực hiện tập trung vào các khu vực cảng của Phú Quốc và khu vực có rạn san hô đợt tháng 5/2009 cho kết quả nồng độ dầu trong nước khá cao, dao động từ 0,21 đến $1,94 \mathrm{mg} / \mathrm{l}$, trung bình 0,69 mg/l, với số lượng mẫu vượt GHCP là $100 \%$. Đặc biệt nồng độ dầu trong lớp nước mặt tại khu vực cảng Dương Đông đo được là 1,94mg/l, gấp gần 10 lần GHCP (hình 9).

Đợt quan trắc tháng 10/210 cho thấy, nồng độ dầu trong nước trong khoảng 0,06 đến $0,51 \mathrm{mg} / \mathrm{l}$, trung bình tầng mặt là $0,25 \mathrm{mg} / \mathrm{l}$, trung bình tầng đáy là $0,14 \mathrm{mg} / \mathrm{l}$, số lượng mẫu vượt GHCP là $33 \%$. Kết quả khảo sát cũng đã xác định nồng độ dầu có xu hướng giảm từ ven bờ đến xa bờ (hình 10).

Đánh giá chung, nồng độ dầu trung bình trong nước đảo Phú Quốc qua các đợt quan trắc từ năm 2007 đến 2010 dao động từ 0,14 đến $0,69 \mathrm{mg} / \mathrm{l}$. So với GHCP đối với nước ven bờ theo QCVN 10: 2008/BTNMT đối với nước các nơi khác $(0,20 \mathrm{mg} / \mathrm{l})$, nồng độ dầu tháng 12 - 2007 cao hơn GHCP 1,2 và nồng độ dầu tháng 5/2009 cao hơn GHCP 3,5 lần, trong đó nồng độ cao tập trung tại các khu vực cảng An Thới và Dương Đông. 




Hình 9: Nồng độ dầu trong nước đảo Phú Quốc tháng 5 - 2009 (Nguồn: Đố Công Thung và nnk, 2010) [15]

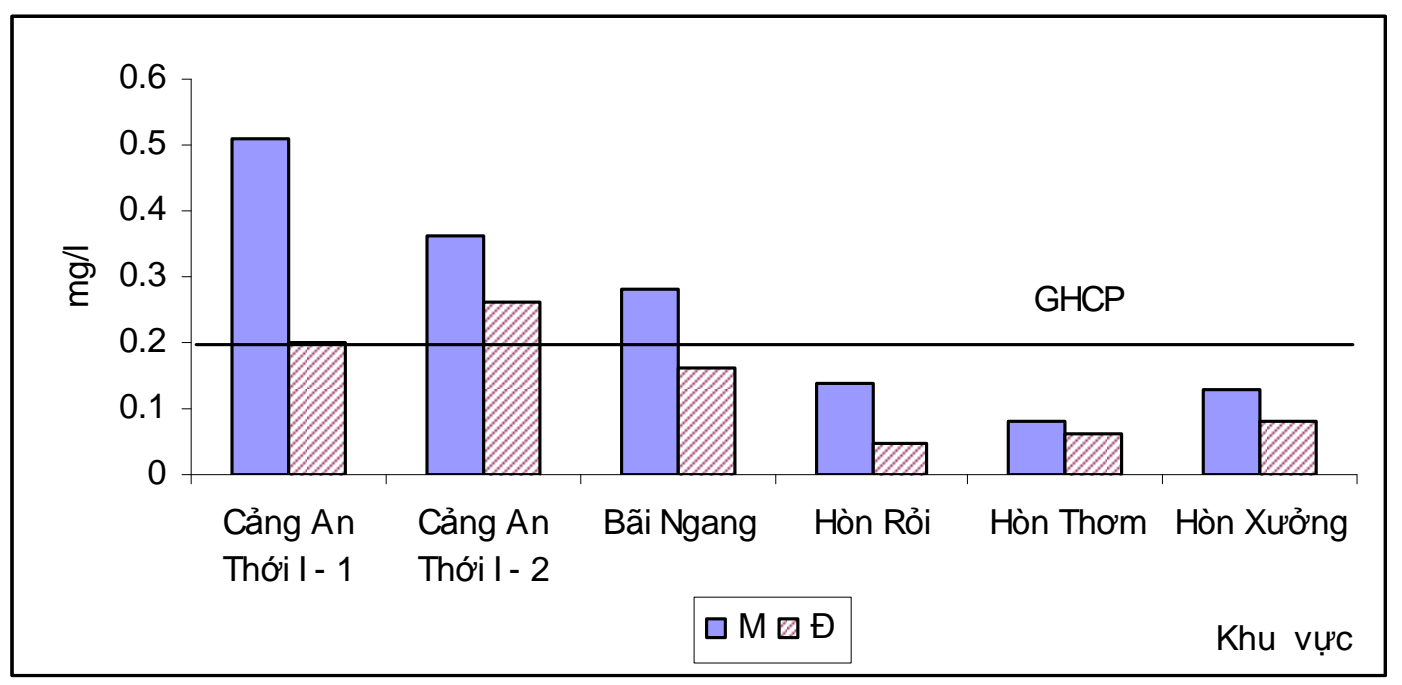

Hình 10. Nồng độ dầu trong nước đảo Phú Quốc tháng 10 - 2010 (Nguồn: Đỗ Công Thung và nnk, 2010) [15]

\section{Tình hình ô nhiễm dầu trong nước dải ven bò̀ Việt Nam}

Tại Việt Nam, nồng độ dầu trong nước biển đã được quan trắc từ năm 1995 trong khuôn khổ các trạm quan trắc môi trường biển Quốc gia ở 3 khu vực miền Bắc, miền Trung và miền Nam. Ngoài ra, còn rất nhiều đề tài dự án có liên quan cũng cho ta các số 
liệu nồng độ dầu trong nước biển ở các khu vực như Thừa Thiên Huế, khu vực Cửa Đại, khu vực đảo Cù Lao Chàm, Phú Quốc, Quy Nhơn...

Tại khu vực biển ven bờ phía Bắc, nồng độ dầu trung bình trong nước biển từ năm 2004 đến 2008 dao động từ 0,14 đến $1,92 \mathrm{mg} / \mathrm{l}$, hầu hết có giá trị lớn hơn GHCP theo QCVN 10:2008 đối với nước biển ven bờ $(0,2 \mathrm{mg} / \mathrm{l})$. Khu vực Cửa Lục có nồng độ dầu cao hơn so với các trạm của vùng biển phía Bắc (hình 11).

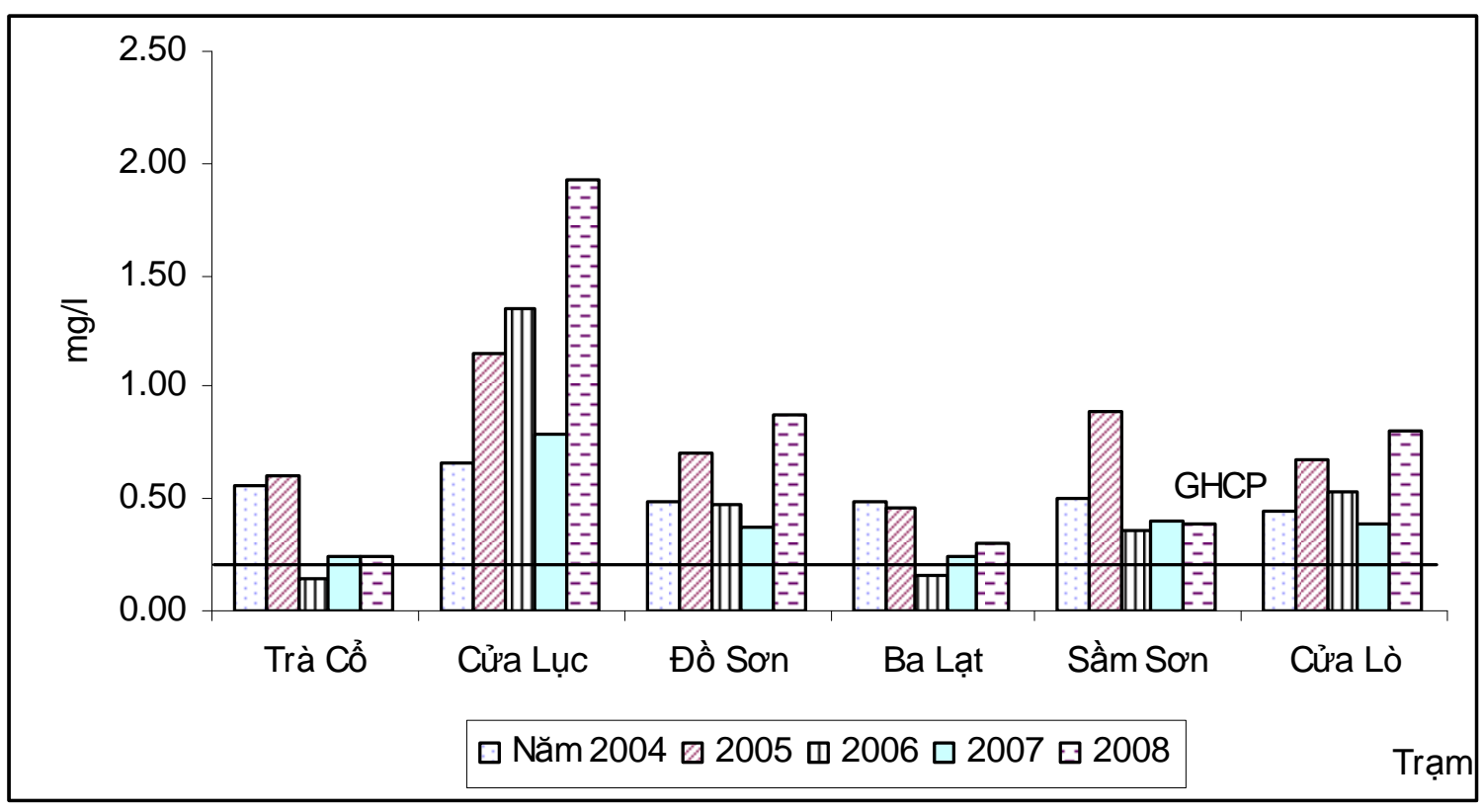

Hình 11: Diễn biến nồng độ dầu trong nước vùng biển ven bờ phía Bắc từ năm 2004 - 2008

Tại các khu vực cảng, theo kết số liệu của Cục Hàng hải Việt Nam (2010) [5], tại khu vực cảng Cái Lân, kết quả quan trắc tháng 6/2010 cho thấy nồng độ dầu trong nước dao động từ 0,45 đến $0,9 \mathrm{mg} / \mathrm{l}$, lớn hơn $\mathrm{GHCP}$ từ 2,2 đến 4,5 lần. Tại khu vực cảng Đình Vũ, nồng độ dầu dao động từ 0,25 đến $0,41 \mathrm{mg} / 1$, lớn hơn $\mathrm{GHCP}$ từ 1,2 đến 2 lần. Tại khu vực cảng Diêm Điền, nồng độ dầu trong nước dao động từ 0,29 đến $0,52 \mathrm{mg} / \mathrm{l}$, lớn hơn GHCP từ 1,5 đến 2,6 lần. Tại khu vực đầm Thị Nại và vịnh Quy Nhơn, nồng độ dầu quan trắc vào tháng 4/2008 và tháng $11 / 2009$ có giá trị 0,01 đến $0,02 \mathrm{mg} / 1$, thấp hơn $\mathrm{GHCP}$.

Khu vực Thừa Thiên Huế, từ năm 2004 đến 2010, nồng độ dầu trung bình trong nước biển dao động từ 0,32 đến $2,04 \mathrm{mg} / \mathrm{l}$, với giá trị cao nhất đo được vào năm 2006 . Hầu hết các mẫu thu được đều có giá trị lớn hơn $\operatorname{GHCP}(0,2 \mathrm{mg} / \mathrm{l})$.

Khu vực biển Cửa Đại, nồng độ dầu trong nước dao động từ 0,3 đến 1,56 mg/l (tại Duy Nghĩa) (số liệu năm 2008) (Trần Đức Thạnh và nnk, 2009)[11]. So với GHCP (0,2 
$\mathrm{mg} / \mathrm{l})$ thì nồng độ dầu trong nước khu vực nghiên cứu bị ô nhiễm bởi dầu từ 1,5 đến 7,8 lần. Ở nồng độ dầu này có thể gây chết các sinh vật phù du (Bùi Đức Nhuận, 2001). Ngoài ra, với nồng độ dầu này có thể gây hại với các sinh vật khác như động vật phù du, chim biển, cá biển...

Nồng độ dầu trong nước tầng mặt vùng biển Cù Lao Chàm dao động từ 0,03 đến $0,27 \mathrm{mg} / \mathrm{l}$, trung bình $0,15 \mathrm{mg} / \mathrm{l}$ (số liệu năm 2002). So sánh với tiêu chuẩn chất lượng nước biển $(0.2 \mathrm{mg} / \mathrm{l})$ thì một số mẫu có biểu hiện ô nhiễm dầu. Các kết quả khảo sát năm 2008 cho thấy nồng độ dầu trong nước khu vực đảo Cù Lao Chàm tại tầng mặt dao động từ $0,4 \mathrm{mg} / \mathrm{l}$ đến $3,82 \mathrm{mg} / \mathrm{l}$, trung bình $2,11 \mathrm{mg} / \mathrm{l}$. Tại tầng đáy nồng độ dầu trong nước dao động từ $0,38 \mathrm{mg} / \mathrm{l}$ đến $1,68 \mathrm{mg} / \mathrm{l}$, trung bình $1,03 \mathrm{mg} / \mathrm{l}$. Có sự gia tăng khá rõ nét về nồng độ dầu trong nước khu vực này với giá trị vượt GHCP từ 2 đến 19 lần (Đỗ Công Thung và nnk, 2009). Các khu vực Cửa Đại và Cù Lao Chàm có nồng độ dầu khá cao là do ảnh hưởng của sự cố tràn dầu tại dải ven biển miền Trung tháng 2 năm 2007 [19].

Khu vực biển Quy Nhơn, các kết quả quan trắc vào tháng 5/2009 tại Nhơn Lý cho thấy nồng độ dầu trong nước dao động từ 0,19 đến $0,57 \mathrm{mg} / \mathrm{l}$, trung bình $0,31 \mathrm{mg} / \mathrm{l}$, hầu hết các mẫu có nồng độ vượt GHCP.

Khu vực biển Vũng Tàu, nồng độ dầu trung bình trong nước dao động từ 0,32 đến $1,12 \mathrm{mg} / \mathrm{l}$, vượt GHCP. Giá trị cao thu được vào đợt thu mẫu năm 2008 .

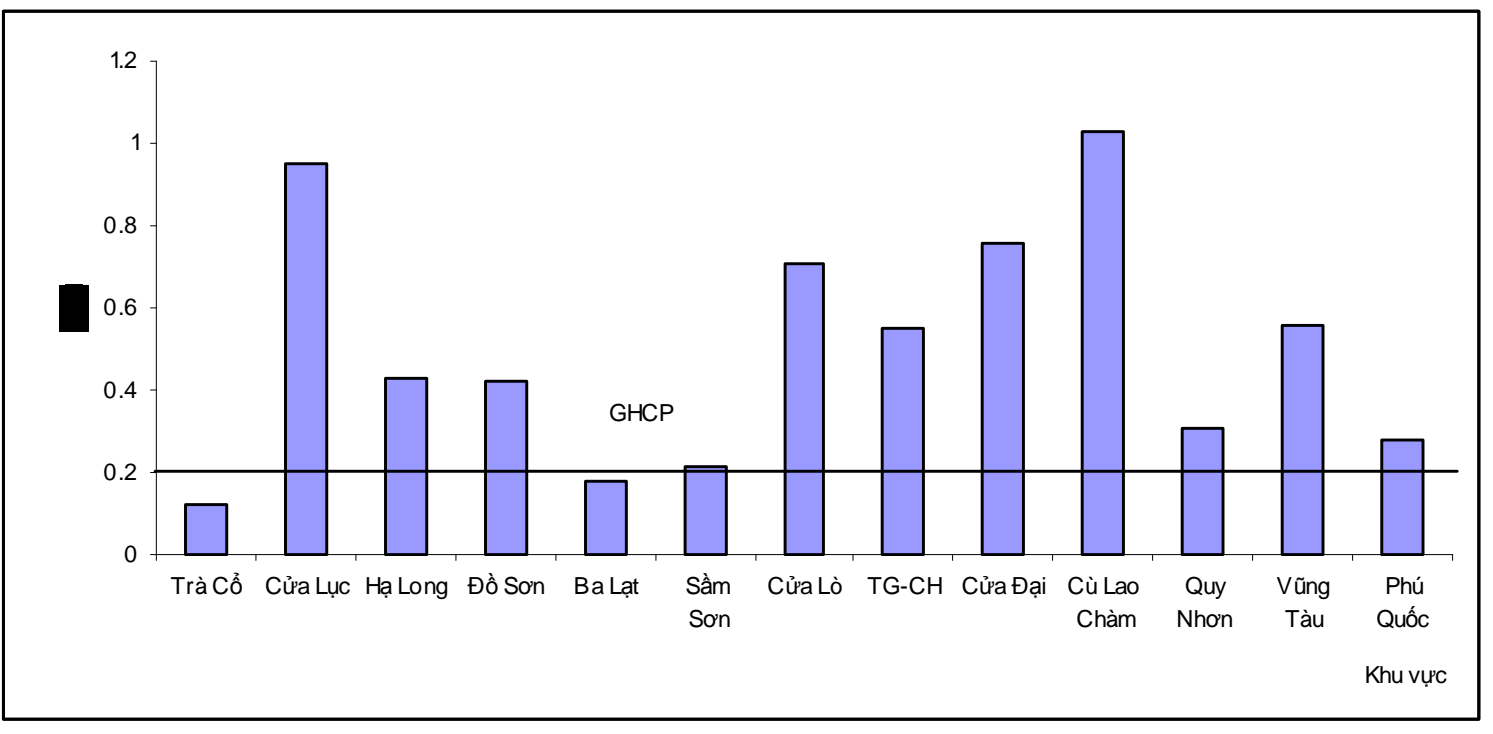

Hình 12: Nồng độ trung bình của dầu trong nước vùng ven biển Việt Nam năm 2008 - 2010 
Khu vực biển Phú Quốc, các kết quả quan trắc từ năm 2007 đến 2010 cho thấy nồng độ dầu trong nước biển dao động từ 0,17 đến $0,69 \mathrm{mg} / \mathrm{l}$, trong đó các giá trị cao bắt gặp vào đợt quan trắc tháng 5/2009.

Nhìn chung, trên toàn dải ven biển Việt Nam, nồng độ dầu trong nước biển đã vượt GHCP đối với nước biển ven bờ. Tuy nhiên, có thể chia là 3 mức độ: ô nhiễm nhẹ, ô nhiễm trung bình và ô nhiễm nặng. Hình 12 cho thấy các khu vực có biểu hiện ô nhiễm nhẹ bởi dầu là Trà Cổ, Ba Lạt. Các khu vực có biểu hiện ô nhiễm trung bình là Vịnh Hạ Long, Đồ Sơn, Tam Giang - Cầu Hai, Quy Nhơn, Vũng Tàu và Phú Quốc. Một số khu vực có dấu hiệu ô nhiễm dầu mỡ cao trong nước là Cửa Lục, Cửa Lò, Cửa Đại và ven đảo Cù Lao Chàm. Tuy nhiên các đánh giá, so sánh trên chỉ mang tính tương đối do thời điểm thu mẫu khác nhau, song cũng phần nào phản ánh bức tranh về tính hình ô nhiễm dầu trên toàn dải ven biển Việt Nam.

\section{KẾT LUẬN}

Các kết quả thu thập tài liệu và điều tra khảo sát về tình hình ô nhiễm dầu trong nước biển vùng ven bờ Việt Nam cho thấy nước biển Việt Nam đã bị ô nhiễm bởi dầu mỡ khi so sánh với QCVN 10: 2008 đối với nước biển ven bờ dùng cho các mục đích khác $(0,2 \mathrm{mg} / \mathrm{l})$. Mặc dù số liệu không đồng bộ về thời gian quan trắc, song có thể thấy rằng các khu vực có biểu hiện ô nhiễm nhẹ bởi dầu là Trà Cổ, Ba Lạt. Các khu vực có biểu hiện ô nhiễm trung bình là vịnh Hạ Long, Đồ Sơn, Tam Giang - Cầu Hai, Quy Nhơn, Vũng Tàu và Phú Quốc. Một số khu vực có dấu hiệu ô nhiễm dầu mỡ cao trong nước là Cửa Lục, Cửa Lò, Cửa Đại và ven đảo Cù Lao Chàm. Tuy các đánh giá, so sánh trên chỉ mang tính tương đối do thời điểm thu mẫu khác nhau, song cũng phần nào phản ánh bức tranh về tính hình ô nhiễm dầu trên tòan dải ven biển Việt Nam.

Nguy cơ gia tăng nồng độ dầu trong nước biển có thể được nhìn thấy do các hoạt động kinh tế liên quan ngày càng gia tăng như việc đẩy mạnh khai thác dầu khí trên thềm lục địa, việc đưa vào sử dụng nhà máy lọc dầu Dung Quất, sự gia tăng sản lượng hàng hóa qua các cảng biển cùng với sự gia tăng số lượng tàu thuyền vào cảng. Xu thế gia tăng hàm lượng dầu trong nước đã được quan sát từ năm 2004 đến 2010 tại các trọng điểm khảo sát đặc biệt là Vịnh Hạ Long, Tam Giang - Cầu Hai, Phú Quốc và một số khu vực biển ven bờ phía Bắc. Điều này cho thấy, việc kiểm soát các nguồn thải dầu mỡ trên vùng biển là hết sức cần thiết để góp phần giữ gìn chất lượng môi trường, bảo vệ nguồn tài nguyên biển và đa dạng sinh học. 


\section{TÀI LIỆU THAM KHẢO}

1. APHA, 2002. Standard Methods for the Examination of Water and Wastewate, 20th ed. Wasington, DC 20005, 2002.

2. Nguyễn Hữu Cử, 2005. Tổng quan môi trường đầm phá ven bờ miền trung Việt Nam. Báo cáo chuyên đề thuộc đề tài đầm phá 14EE5. Lưu tại Viện Tài nguyên và Môi trường Biển.

3. Nguyễn Hữu Cử, 2006. Nghiên cứu động thái môi trường đầm phá ven bờ miền Trung Việt Nam làm cơ sở lựa chọn phương án quản lý. Dự án hợp tác Việt Nam Italia theo Nghị định thư.

4. Nguyễn Hữu Cử, Trần Đức Thạnh, Nguyễn Thị Kim Anh, 2008. Kiểm kê đánh giá các khu vực, đối tượng có giá trị kỳ quan thiên nhiên, di sản tự nhiên ở vùng biển và ven bờ tỉnh Thừa Thiên Huế.

5. Cục Hàng hải Việt Nam, 2010. Dự thảo báo cáo "Tình hình tác động môi trường lĩnh vực hàng hải giai đoạn 2006 - 2010 và xây dựng kế hoạch giảm thiểu ô nhiễm giai đoạn 2011 - 2020.

6. Lưu Văn Diệu, 2002. Dầu tràn trên biển. Kỷ yếu hội thảo "Quản lý môi trường cảng tại Việt Nam", biên tập Luc Hens, Trần Đình Lân.

7. Dự án IMOLA Huế GCP/VIE/029/ITA, 2007. Tài nguyên và Môi trường đầm phá Tam Giang - Cầu Hai.

8. Nguyễn Chu Hồi, 1998. Đề án hợp tác ASEAN-Canada về khoa học biển giai đoạn II - CPMS-II. Việt Nam, tháng 6/1998. Tài liệu lưu trữ tại Viện Tài nguyên và Môi trường Biển.

9. Nguyễn Thanh Hùng, 2005. Báo cáo kiểm kê cảng Vũng Tàu. Báo cáo công việc trong khuôn khổ dự án VN/ASIA Pro Eco/01 (91168) Thiết lập cơ sở khoa học trong hỗ trợ quản lý môi trường cảng ở Việt Nam và Campuchia.

10. Bùi Đức Nhuận, 2001. Về quy hoạch tổng thể phát triển hệ thống cảng biển đến năm 2010. Tạp chí biển N0 3-2001.

11. Trần Đức Thạnh, Đỗ Công Thung và nnk, 2008. Điều tra, khảo sát, đánh giá thiệt hại về kinh tế, môi trường và ảnh hưởng đến các hệ sinh thái biển, đề xuất biện pháp trước mắt và lâu dài để phục hồi môi trường các khu vực bị ô nhiễm dầu tại Cù Lao Chàm và Cửa Đại (tỉnh Quảng Nam).

12. Đỗ Công Thung, 2005. Sử dụng bền vững và bảo tồn đa dạng sinh học đầm phá 
Tam Giang - Cầu Hai. Hội thảo Quốc gia về đầm phá Thừa Thiên Huế.

13. Đỗ Công Thung, 2005. Đánh giá ảnh hưởng tràn dầu tại Vũng Tàu. Đề tài cấp cơ sở năm 2008.

14. Đỗ Công Thung, 2009. Nghiên cứu, đánh giá các giá trị đa dạng sinh học vịnh Hạ Long phục vụ cho việc quản lý, phát huy giá trị đa dạng sinh học của của di sản.

15. Đỗ Công Thung, 2010. Xây dựng cơ sở khoa học, pháp lý cho việc đánh giá và đòi bồi thường thiệt hại do ô nhiễm dầu gây ra trên vùng biển Việt Nam. Đề tài độc lập cấp Nhà nước giai đoạn 2009 - 2010.

16. Trạm Quan trắc và Phân tích môi trường Biển miền Bắc, 2004 - 2010. Tập báo cáo quý và báo cáo tổng kết hàng năm. Tài liệu lưu giữ tại Viện Tài nguyên và Môi trường Biển.

17. Nguyễn Văn Tiến, 2007. Điều tra nguồn lợi san hô và thảm cỏ biển Phú Quốc 2005 - 2007.

18. Nguyên Văn Tiến, 2007. Điểm trình diễn rạn san hô và thảm cỏ biển tại Phú Quốc trong khuôn khổ Dự án khu vực (UNEP/GEF/SCS): "Ngăn ngừa xu hướng suy thoái môi trường Biển Đông và vịnh Thái Lan".

19. vietnamnet.vn. Nhiều vết dầu loang ven biển miền Trung. Cập nhật ngày 2/2/2007.

20. Nguyễn Huy Yết, Nguyễn Thị Thu và nnk, 2010. Đánh giá mức độ suy thoái các hệ sinh thái ven bờ biển Việt Nam và đề xuất các giải pháp quản lý bền vững. Đề tài cấp Nhà nước giai đoạn 2009 - 2010.

\section{OIL POLLUTION IN COASTAL WATER OF VIETNAM}

\section{CAO THI THU TRANG, VU THI LUU}

Summary: The survey data of oil concentration in coastal water of Viet Nam in last ten years shown that the water is polluted by oil and grease and the pollution is more increased day by day. The oil pollution is caused by the exploitation of oil in continental shelf, the processes of refined oil factories, activities of seaport system in the coastal water, oil spill and maritime accidents. The latest surveys in 2009 - 2010 at 4 major points Ha Long Bay, Tam Giang - Cau Hai lagoon, Vung Tau and Phu Quoc show the increasing of oil content in sea water. It indicates that the control of oil wastes is very necessary in order to improve environmental quality, protect marine resources and biodiversity.

Ngày nhận bài: 24 - 3 - 2011

Ngưòi nhận xét: PGS. TS. Đỗ Công Thung 